\title{
Formulasi Model Kepemimpinan Selama Pandemi Covid-19 Pada Pimpinan Bank Mandiri Region Bandung Sebagai Upaya Menjaga Profitabilitas Perusahaan
}

$\begin{array}{lr} & \begin{array}{r}\text { Riyanto* } \\ \text { Submitted Date : } \\ 25 \text { August 2021 } \\ \text { Accepted Date : } \\ 29 \text { November 2021 }\end{array} \quad \begin{array}{r}\text { Universitas Padjadjaran } \\ \text { riyanto1981@yahoo.com }\end{array} \\ \begin{array}{r}\text { Erie Febrian } \\ \text { Universitas Padjadjaran }\end{array} \\ \text { John Sihotang }\end{array}$

\section{Suggested Citation:}

Drobyazko, S., Okulich-Kazarin, V., Rogovyi, A., Goltvenko, O., \& Marova, S. (2019). Factors of influence on the sustainable development in the strategy management of corporations. Academy of Strategic Management Journal

Abstract:

This study aims to formulate a model of leadership in a strategic management framework referring to the leadership model literature in times of crisis with the results of deep interviews with top leaders in the region. This study uses a qualitative descriptive research approach where this research is a research method that utilizes qualitative data and is described descriptively. The type of research used is descriptive qualitative. The source of data in this study is primary data obtained by conducting questionnaire research in order to become the results and conclusions of the study. Using purposive sampling method. Samples were taken as many as 150 branches with the priority of the above criteria. In this study, it was found that the results of deep interviews and FGDs outline the strategy carried out during the pandemic is a survival strategy or profit strategy where companies seek to find sources of income that can still experience growth such as transactional digital transactions, e-commerce, investment transactions. and minimize the formation of costs arising from the decline in credit quality.

Keywords: Leadership Model; Profitability; Strategic Management-Strategic Execution

Abstrak:

Penelitian ini bertujuan untuk memformulasikan model dari kepemimpinan dalam framework manajemen stratejik mengacu pada literatur model leadership di saat krisis dengan hasil deep interview dengan top leader di region. penelitian ini menggunakan pendekatan penelitian deskriptif kualitatif dimana penelitian ini merupakan sebuah metode penelitian yang memanfaatkan data kualitatif dan dijabarkan sejara deskriptif. Jenis penelitian yang digunakan adalah deskriptif kualitatif Sumber data dalam penelitian ini adalah data primer diperoleh dengan mengadakan penelitian kuesioner agar dapat menjadi hasil dan kesimpulan penelitian. Menggunakan metode purposive sampling. Sampel diambil sejumlah 150 cabang dengan prioritas kriteria di atas. Dalam penelitian ini di temukan bahwa hasil dari deep interview dan FGD secara garis besar strategi yang dijalankan di masa pandemi adalah strategi bertahan atau profit stategi dimana perusahaan berupaya mencari sumber pendapatan yang masih bisa mengalami pertumbuhan seperti transaksional dari transaksi digital, ecommerce, transaksi investasi dan meminimalisasi pembentukan biaya yang timbul akibat penurunan kualitas kredit.

Keywords: Leadership Model; Manajemen Stratejik-Strategic Execution; Profitabilitas

JEL Classification: G21, 015

${ }^{*}$ Corresponding Author 


\section{Latar Belakang}

Peran perbankan di Indonesia dalam menggerakkan perekonomian nasional sangat vital (Sari, 2013). Perbankan berperan hampir disemua aktivitas ekonomi seperti konsumsi, investasi, serta kegiatan ekspor impor, dimana aktivitas tersebut merupakan sektor penggerak utama Produk Domestik Bruto (PDB) Indonesia dan tidak bisa dipungkiri perbankan memiliki peran besar dalam tiga kegiatan dimaksud(Meyliana \& Mulazid, 2017). Sektor konsumsi dan investasi sendiri menyumbang $80 \%$ terhadap Produk Domestik Bruto atau perekonomian secara keseluruhan (Hayet, 2016).

Perbankan yang memiliki peran utama dalam perekonomian yaitu sebagai lembaga perantara atau intermediary yaitu menghimpun dana dari masyarakat dan kemudian menyalurkannya dalam bentuk pinjaman untuk menunjang kegiatan konsumsi dan produksi, hal inilah yang menjadi salah satu faktor pemicu pertumbuhan ekonomi di seluruh sektor (Yusuf, 2016). Adanya pertumbuhan volume kredit perbankan baik kredit konsumtif dan produktif akan meningkatkan daya beli, pertumbuhan usaha, peningkatan laba usaha, hingga peningkatan investasi (Kornita \& Mayes, 2010). Bedasarkan data akhir tahun (2019) rasio aset perbankan terhadap Pendapatan Domestik Bruto (PDB) di Indonesia sebesar 55,01\% hal ini menunjukkan kontribusi sektor perbankan terhadap laju pertumbuhan perekonomian secara keseluruhan cukup signifikan (Masduki, Ida Mursidah, 2020) .Memasuki tahun 2020 kondisi berubah sangat drastis dimana ekonomi mengalami kontraksi sebesar 2.07\% yang dipicu oleh pandemi Covid-19 yang pertama kali teridentifikasi pada tanggal 2 Maret 2020. Industri perbankan juga mengalami penurunan yang tercermin dari penurunan laba perbankan sebesar $-33 \%$ secara year on year 2020, yang dipicu oleh penurunan pendapatan sebagai akibat pertumbuhan kredit yang mengalami kontraksi sebesar 2.41\%(Winasis \& Riyanto, 2020).Selanjutnya penurunan Laba bersih perbankan sebagai dampak pandemic dapat dilihat pada Gambar 1 sebagai berikut:

Gambar 1. Perkembangan Laba Perbankan di Indonesia periode 2016-2020
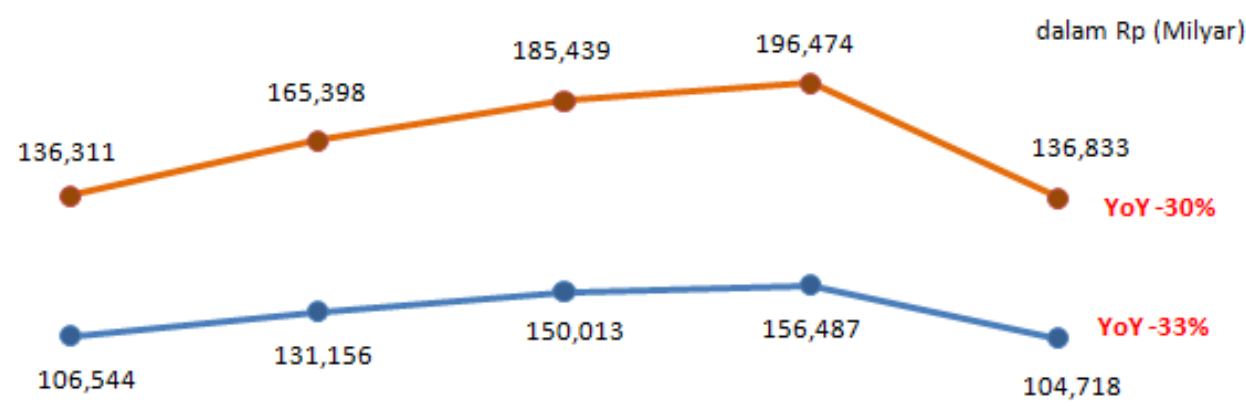

$\begin{array}{lllll}2016 & 2017 & 2018 & 2019 & 2020\end{array}$

\section{Sumber: Otoritas Jasa Keuangan (2020)}

Menurunnya profitabilitas perbankan dimaksud, utamanya diakibatkan oleh kenaikan Cadangan Kerugian Penurunan Nilai (CKPN) masing-masing bank. CKPN adalah merupakan penyisihan dana yang dinilai dari hasil evaluasi pembiayaan debitur oleh masing-masing bank (Winasis \& Riyanto, 2020). Pencadangan tersebut harus dilakukan karena selama masa pandemi, bank-bank tersebut melakukan restrukturisasi besar-besaran terhadap nasabah yang mengalami penurunan kualitas kredit akibat terdampak Covid-19(Kholiq \& Rahmawati, 2020). Restrukturisasi ini juga sejalan dengan Peraturan OJK yang dikeluarkan sejak Maret 2020 dan berlaku hingga Maret 2022(Saraswati, 2020). Peraturan Otoritas Jasa Keuangan No. 11/POJK.03/2020 ini mengatur tentang Stimulus Perekonomian Nasional sebagai Kebijakan Countercyclical Dampak Penyebaran Corona Virus Disease 2019, yang didalamnya mengatur mengenai kebijakan bagi bank yang mendukung stimulus pertumbuhan ekonomi untuk debitur yang terkena dampak penyebaran Covid-19 termasuk debitur UMKM, dengan tetap memperhatikan prinsip kehati-hatian (restrukturisasi) (Benuf, 2020).

Pandemi Covid-19 yang melanda Indonesia dan seluruh dunia, diantisipasi dengan berbagai kebijakan di semua bidang. Pembatasan sosial dan bisnis yang bertujuan mengurangi dan menghentikan dampak penyebaran virus, ternyata menimbulkan dampak pada perekonomian dan bisnis di Indonesia Dampak Covid-19 
ini berakibat pada penurunan pendapatan pada perusahaan-perusahaan dimana besar atau kecilnya penurunan bergantung pada skala perusahaan (mikro, kecil, menengah dan besar) juga terkait lokasi usaha dan sektor usaha. Secara umum $82.85 \%$ perusahaan diberbagai sektor usaha mengalami penurunan pendapatan, $14.60 \%$ tetap serta hanya 2.25\% perusahaan yang mengalami peningkatan pendapatan saat pandemi (Hastuti, 2021).

Pemberlakukan physical distancing dan Pembatasan Sosial Berskala Besar (PSBB) akibat pandemi Covid-19 berimbas pada operasional perusahaan. Bahkan yang lebih parah lagi, seperti dilaporkan Bisnis Indonesia, sekitar 43.000 buruh di Jawa Barat juga dirumahkan sejak Maret 2020 akibat corona. Perusahaanperusahaan yang merumahkan pekerjanya tersebut beralasan karena mesin-mesin tidak produksi bahkan banyak perusahaan gulung tikar. Jika sebuah perusahaan tidak produksi, maka tidak ada orderan hingga pemasukan.

Kondisi pandemi covid-19 serta dampak yang ditimbulkannya menjadi menarik bagaimana kita menganalisis perusahaan-perusahaan di Provinsi di Jawa Barat dalam merespon kondisi selama masa Pandemi ini, bagaimana mereka bertahan dan strategi apa yang diambil terutama pada level korporasi sehingga masih bisa menjaga profitabilitasnya(Winanto et al., 2020). Profitabilitas dimaksud disini adalah keefektifan manajemen secara keseluruhan sebagaimana ditunjukkan oleh pengembalian (return) yang diperoleh dari penjualan dan investasi(Mutsanna \& Sukirno, 2020). Ada beberapa tolak ukur yang bisa digunakan oleh perusahaan untuk mengukur profitabilitas yang biasanya dikaitkan dengan volume penjualan, total aktiva dan modal yang dimiliki (Dewi et al., 2016). Adapun rasio-rasio yang biasa digunakan untuk mengukur profitabilitas perusahaan meliputi: Gross Profit Margin (Margin Laba Kotor), Return on Investment (Pengembalian atas Investasi), Return on Equity (Pengembalian atas Ekuitas Pemegang Saham), Earning per Share (Laba per Saham), Net Profit Margin (Margin Laba Bersih), Operating Profit Margin (Margin Laba Operasi) dan Return on Assets (Pengembalian atas Total Asset) (PONTOH et al., 2016).

Sektor Perbankan merupakan salah satu sektor yang penting untuk dijaga selama masa pandemi, hal ini dibuktikan selama masa pandemi pemerintah memutuskan untuk fokus memperhatikan tiga sektor, yaitu sektor kesehatan, sektor riil, dan sektor perbankan. Fokus pemerintah tersebut tecermin dari alokasi Anggaran Pengeluaran dan Belanja Negara (APBN) 2020 dan langkah kebijakan Bank Indonesia untuk meningkatkan likuiditas atau kemampuan bank untuk memenuhi kewajiban finansialnya yang akan jatuh tempo(Burhanuddin, 2020).Adanya pandemi Covid-19 menyebabkan disrupsi bagi seluruh industri. Hampir semua perusahaan dipaksa melakukan transformasi besar-besaran secara mendadak dan cepat(Yahya, 2021). Krisis multi dimensi sebagai akibat Pandemi Covid-19 ini memberikan tantangan tersendiri bagi pimpinan perusahaan (Leader), dimana sebagai pimpinan harus memberikan arah kebijakan maupun strategi yang sesuai sehingga keberlangsungan perusahaan kedepan dapat dijaga (Rosyada \& Wigiawati, 2020).

Hal pertama yang harus dilakukan oleh seorang pemimpin dalam perusahaan adalah menyadari bahwa perusahaan yang mereka pimpin menghadapi krisis. Hal ini merupakan langkah yang cukup sulit, terutama di saat krisis datang perlahan dan berkembang di dalam situasi yang terlihat wajar sehingga tidak terlihat secara nyata (Wibowo, S. W., \& Negara, 2021). Untuk mengantisipasi ancaman potensial dari krisis yang berkembang dengan lambat ini, para leader perlu mengurangi terjadinya bias kenormalan, yang dapat menyebabkan mereka tidak dapat merespon dengan baik adanya kemungkinan maupun dampak yang dapat ditimbulkan (Sidik, A. R., \& Sutoyo, 2020). Ketika para leader menyadari terjadinya krisis, mereka dapat memulai memikirkan bagaimana merespon terhadap peristiwa tersebut. Namun demikian, mereka tidak dapat mengantisipasi seperti dalam dalam keadaan darurat biasa dimana tindakan biasanya dilakukan mengikuti rencana yang telah disusun sebelumnya. Selama masa krisis dimana terdapat banyak ketidak normalan dan ketidakpastian, perlu dilakukan penyesuaian besar untuk memberikan respon secara efektif (Naway, 2017).

Penelitian tentang faktor-faktor yang mempengaruhi kinerja perusahaan menunjukkan adanya korelasi yang positif antara perencanaan strategi dan kinerja yang dihasilkan. Dengan kata lain, bahwa perusahaan yang menggunakan manajemen stratejik akan memperoleh tingkat kinerja yang lebih tinggi(Drobyazko et al., 2019).Manfaat terbesar dari manajemen stratejik adalah menimbulkan kesempatan untuk terjadinya proses pemberdayaan individu, walaupun proses pengambilan keputusan stratejik adalah tanggung jawab utama dari pemilik perusahaan atau CEO, namun baik manajer maupun karyawan harus juga terlibat secara aktif dalam aktivitas formulasi strategi, implementasi dan evaluasi inilah yang dimaksud dengan proses pemberdayaan (empowering)(Wang et al., 2019). 
Dengan demikian peran pemimpin dan kebijakan/ strategi apa yang diambil saat terjadinya krisis sangat menentukan arah perusahaan kedepannya. Hal ini juga pernah diungkap pada penelitian yang dilakukan oleh (Forster et al., 2012) dengan melakukan wawancara terhadap 259 Senior Executive perusahaan yang masuk dalam Fortune 500 di Amerika Serikat yang pada intinya menyatakan bahwa kunci sukses perusahaan dalam menghadapi perubahan 92\% ditentukan oleh peran pimpinan leadership. Kunci keberhasilan dalam mengeksekusi strategi dimaksud menurut Arnoud adalah sinergi atas tiga hal yaitu process-content-context, dimana peran seorang pemimpin dalam menjalankan fungsinya (leaderhip) sangat dominan, seorang pimpinan dituntut untuk dapat menjabarkan dan menyampaikan strategi yang jelas ke semua tim sehingga mereka bersedia melakukan apa yang menjadi arah kebijakan perusahaan sehingga tingkat keberhasilan dari strategi yang dirumuskan sebelumnya menjadi tinggi (Ghufron, 2020).

Selama masa krisis sebagai akibat Pandemi saat ini, perusahaan industri jasa keuangan termasuk di dalamnya perbankan memasuki tahapan siklus decline, dimana fokus dan strategi perusahaan adalah bagaimana menjaga dan mempertahankan profitabilitas (profit strategy) kemungkinan adanya penurunan skala bisnis (retrenchment)(Yanto \& Sukanta, 2020). Fase ini menjadi sangat critical karena jika perusahaan dapat melewatinya dengan baik maka akan dapat melanjutkan ke fase growth lebih lanjut dan jika tidak dapat melewati dengan baik bisa memasuki fase death atau keberlangsungan perusahaan akan terancam(Simanjuntak et al., 2020). Peran Leader dan leadership kaitannya dengan proses Manajemen Stratejik yang yang dirumuskan oleh (Wheelen \& Hunger, 2016), ditegaskan bahwa peran kepemimpinan sangat diperlukan dalam setiap tahapan Strategic Management Proses yang bisa digambarkan dalam diagram berikut:

Gambar 2. Elemen Dasar dalam Proses Manajemen Stratejik

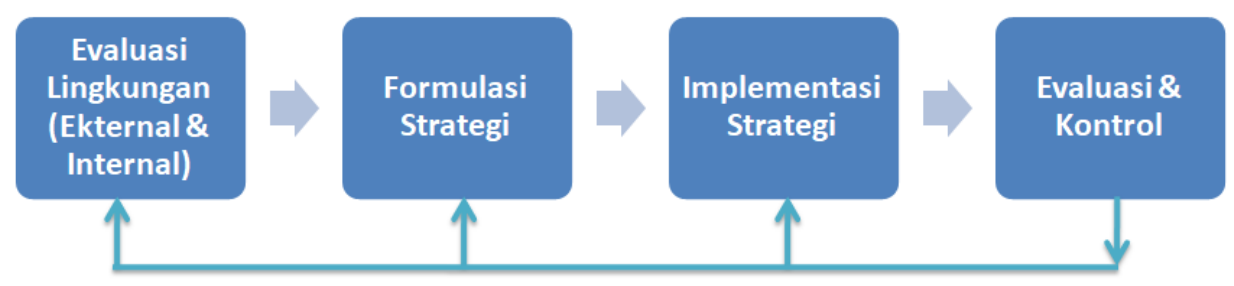

Sumber : (Wheelen \& Hunger, 2016)

Bagaimana peran leadership dalam kondisi pandemi seperti saat ini, dalam penelitian Smet \& D'Auria, (2020) mencoba memformulasikan peranan leadership pada saaat terjadi pandemi virus corona atau krisis, dimana krisi kali ini sangat berbeda dari yang pernah terjadi sebelumnya, setidaknya terdapat 5 (lima) praktik kepemimpinan/ leadership yang dapat membantu dalam merespon kondisi dimaksud secara efektif, yaitu Mempersiapkan untuk merespon krisis dengan membentuk jaringan satuan tugas (satgas); memperkuat karakter kepimpinan dalam masa krisis, merupakan manfaat atas sikap deliberate calm dan bounded optimism; membuat keputusan di tengah ketidakpastian, berhenti sejenak untuk menilai dan mengantisipasi, lalu bertindak; menunjukkan empati, menghadapi tragedi kemanusiaan sebagai prioritas pertama; berkomunikasi secara efektif, mempertahankan transparasi dan memberikan pemberitahuan secara rutin.

Kelima praktik kepemimpinan merupakan salah satu contoh yang bisa digunakan sebagai rujukan untuk memformulasikan model kepemimpinan yang harus dilakukan saat pandemi. selain rujukan dari beberapa teori dan jurnal terkait kepemimpinan di masa pandemi atau krisis. Selanjutnya dari kajian tersebut nantinya perlu dilakukan validasi dengan praktik yang dilakukan para pimpinan di lapangan baik yang berhasil maupun yang mengalami kegagalan selama masa pandemi ini(Smet \& D’Auria, 2020).

Penelitian ini mencoba memformulasikan bagaimana bentuk kepemimpinan atau Leadership Model dimasa pandemi terutama di level Area dan Segment Bisnis di Bank Mandiri Regional Bandung sehingga nantinya akan tersusun perilaku (behavior) dan kompetensi (competency) minimum yang harus dimiliki oleh seorang pemimpin dimasa pandemi terutama dikaitkan dengan profitabilitas perusahaan. Selanjutnya Model Kepemimpinan (Leadeship Model) tersebut diharapkan dapat membantu para pemimpin untuk mengambil tindakan terbaik dan terstruktur dalam mengatasi pandemi virus corona dan krisis lainnya di masa depan, yang pada akhirnya dapat menjaga keberlangsungan perusahaan terutama ditinjau dari sisi profitabilitas(Godfrey, 2016). 


\section{Metode Penelitian}

Penelitian ini menggunakan pendekatan penelitian deskriptif kualitatif dimana penelitian ini merupakan sebuah metode penelitian yang memanfaatkan data kualitatif dan dijabarkan sejara deskriptif. Sumber data dalam penelitian ini adalah data primer diperoleh dengan mengadakan penelitian kuesioner agar dapat menjadi hasil dan kesimpulan penelitian (Sugiyono, 2015). Peneliti menggunakan metode purposive sampling, yang mana peneliti mempertimbangkan 2 kriteria yang bisa mewakili pencapaian profitabilitas yaitu Revenue Growth dan pencapaian target volume dari masing-masing unit kerja atau unit bisnis yang berada dibawah koordinasi Bank Mandiri Region Bandung. Sampel diambil sejumlah 150 cabang dengan prioritas kriteria di atas dan memenuhi confidance Interval 95\% menggunakan pendekatan Nomogram Harry King. Penelitian ini menggunakan metode Delphi yang merupakan proses yang dilakukan dalam kelompok untuk mensurvei dan mengumpulkan pendapat dari para ahli terkait topik tertentu. Pada penelitian ini responden akan dibagi menjadi 2 (dua) kelompok:

1. Kelompok 1, terdiri dari 5-10 Orang Top Leader untuk melakukan eksplorasi atau mendisikusikan jenis-jenis kompetensi yang relevan terkait Leadership Model dan Manajemen Stratejik Proses

2. Kelompok 2, yang terdiri dari 10-20 Orang Lini Manager, yang melakukan verifikasi dengan merating/mengurutkan kompetensi yang telah dirumuskan oleh kelompok 1, dan hasil dari verifikasi/lterasi kelompok 2 inilah yang nantinya yang menjadi hasil penelitian atau rujukan Leadership Model yang ideal.

\section{Hasil}

Berdasarkan hasil studi literatur dan kajian jurnal yang diperkuat dengan Deep Interview serta Focus Group Discussion (FGD), tantangan Leadership di Masa Pandemi saat ini tidak lepas dari dampak adanya Pandemi itu sendiri dan Proses yang sedang berlangsung saat ini yang merupakan respon dari dampak pandemi, setidaknya terdapat 3 faktor utama yang berpengaruh pada leader dalam menentukan arah kebijakan perusahaan atau strategi dan bagaimana melakukan kepemimpinannya/ leadership selama masa pandemi, dimana tujuan utamanya menjaga eksistensi perusahaan dan daya saing yang pada akhirnya mempertahankan Profitabilitas, yaitu Perubahan Perilaku Konsumen (Changing in Customer Bahvior), Era Disrupsi dan Digitalisasi yang dipercepat (Disruption \& Accelerated Digitalization), dan Peta Persaingan yang semakin luas yang tidak hanya datang dari sesama Industri Perbankan namun juga Fintech.

Formulasi Leadership Model, dari proses penyusunan kerangka pikir penelitian hingga prioritisasi dan validasi hasil Deep Interview dan FGD dapat diperoleh hasil sebagai berikut:

Tabel 1. Tabulasi Hasil Penelitian

\begin{tabular}{|c|c|c|c|}
\hline Attribute & $\begin{array}{l}\text { Leader Level } 1 \text { (Top Leader: } \\
\text { RCO \& Deputy) }\end{array}$ & $\begin{array}{c}\text { Leader Level } 2 \\
\text { (Middle Management: Segment } \\
\text { Head \& Area Head) }\end{array}$ & $\begin{array}{c}\text { Leader Level } 3 \text { (Line Manager: } \\
\text { Branch Manager) }\end{array}$ \\
\hline $\begin{array}{l}\text { CONSEPTUAL } \\
\text { (Strategic } \\
\text { Domain) }\end{array}$ & $\begin{array}{l}\text { 1. Clear Vision and Strategy } \\
\text { 2. Competent Leader } \\
\text { 3. Creative and Innovative }\end{array}$ & $\begin{array}{l}\text { 1. Clear Vision and Strategy } \\
\text { 2. Competent Leader } \\
\text { 3. Creative and Innovative }\end{array}$ & $\begin{array}{l}\text { 1. Clear Vision and Strategy } \\
\text { 2. Competent Leader } \\
\text { 3. Creative and Innovative }\end{array}$ \\
\hline $\begin{array}{l}\text { PEOPLE } \\
\text { (Interpersonal } \\
\text { Domain) }\end{array}$ & $\begin{array}{l}\text { 1. Develop People } \\
\text { 2. Empowering Team } \\
\text { 3. High Motivation }\end{array}$ & $\begin{array}{l}\text { 1. Empowering Team } \\
\text { 2. Develop People } \\
\text { 3. High Motivation }\end{array}$ & $\begin{array}{l}\text { 1. Develop People } \\
\text { 2. Empowering Team } \\
\text { 3. High Motivation }\end{array}$ \\
\hline $\begin{array}{l}\text { TECHNICAL } \\
\text { (Operational } \\
\text { Domain) }\end{array}$ & $\begin{array}{l}\text { 1. Good Commonication \& } \\
\text { Deliver Message } \\
\text { 2. Entrepreneurship } \\
\text { 3. Deliver Result } \\
\text { 1. Emphaty }\end{array}$ & $\begin{array}{l}\text { 1. Good Commonication \& } \\
\text { Deliver Message } \\
\text { 2. Entrepreneurship } \\
\text { 3. Deliver Result } \\
\text { 1. Adaptive/ Response }\end{array}$ & $\begin{array}{l}\text { 1. Good Commonication \& } \\
\text { Deliver Message } \\
\text { 2. Entrepreneurship } \\
\text { 3. Deliver Result } \\
\text { 1. Emphaty }\end{array}$ \\
\hline $\begin{array}{l}\text { Pandemic } \\
\text { Attributes }\end{array}$ & $\begin{array}{l}\text { 2. Adaptive/ Response } \\
\text { Uncertainty } \\
\text { 3. Agility } \\
\text { 4. Digital Competencies }\end{array}$ & $\begin{array}{l}\text { Uncertanty } \\
\text { 2. Agility } \\
\text { 3. Emphaty } \\
\text { 4. Digital Competencies }\end{array}$ & $\begin{array}{l}\text { 2. Digital Competencies } \\
\text { 3. Adaptive/ Response } \\
\text { Uncertanty } \\
\text { 4. Agility }\end{array}$ \\
\hline
\end{tabular}

Sumber: Data Diolah (2021) 


\section{Pembahasan}

\section{Leadership Model}

Pemimpin harus memiliki kualitas dasar yang meliputi kemampuan memerintahkan dengan cara hormat, yakin atas tujuan yang tulus, percaya akan kemampuan diri, kemampuan untuk menyampaikan pendapat, dapat diterima sebagai pemimpin. Sebagai pemimpin dalam kelompok orang akan menampilkan tipe dan gaya kepemimpinan yang di anggap akan efektif bagi pencapaian tujuan organisasi. Formulasi Leadership Model dihasilkan 3 model Leadership berdasarkan level kepemimpinan yaitu: Leadership Model 1, Leadership Model 2 dan Leadership Model 3. Ketiga model mempunyai atribut yang sama namun berbeda pada prioritas di masingmasing atribut dalam satu domain/kategori leadership. Untuk lebih jelasnya dapat dilihat pada tabel berikut:

Tabel 2. Leadership Model

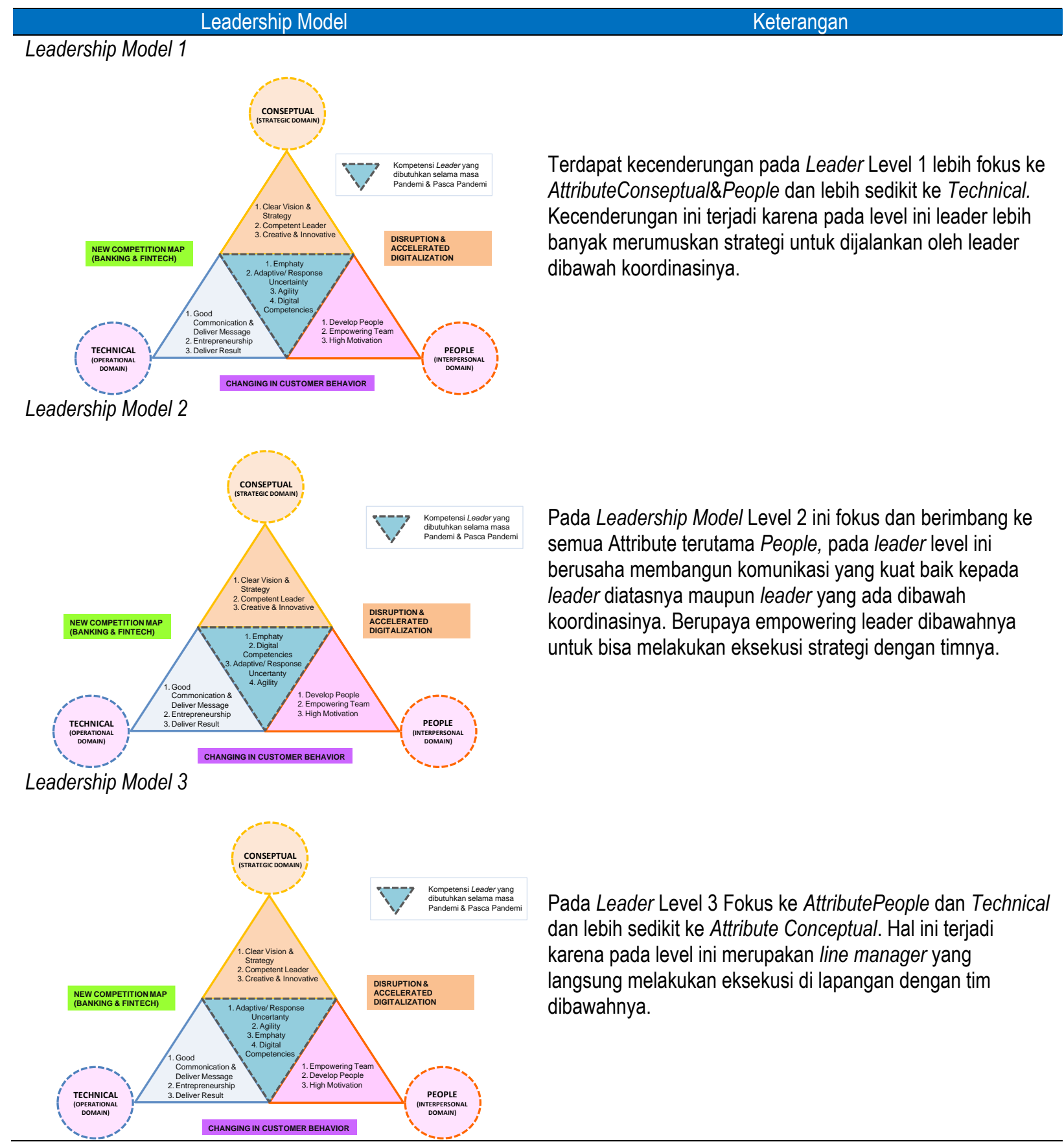

Sumber: Data Diolah (2021) 


\section{Kesesuaian Leadership di Masa Pandemi dengan Leadership Model Klasik}

Selama masa Pandemi merujuk pada Leadership Model Klasik Cai et al., 2019) yaitu Leadership Grid, kecenderungan Leader fokus pada people atau Tim terlebih dahulu, memastikan mereka aman dan sehat (save and secure), membangun awareness atas apa yang terjasi bahwa keselamatan penting dan produktivitas dapat tercapai jika karyawan dalam keadaan sehat. Selanjutnya baru menciptakan operasional bisnis yang aman, dan selanjutnya baru memikirkan bagaimana bisnis tetap berjalan dengan baik dan menghasilkan revenue sebagai upaya untuk menjaga profitabilitas.

Save our Peoples First $\rightarrow$ Do Safety Operations $\rightarrow$ Run business base on fact finding and Current Condition to Maintain Profitability.

\section{Kesimpulan}

Berdasarkan hasil deep interview dan FGD secara garis besar strategi yang dijalankan di masa pandemi adalah strategi bertahan atau profit stategi dimana perusahaan berupaya mencari sumber pendapatan yang masih bisa mengalami pertumbuhan seperti transaksional dari transaksi digital, e-commerce, transaksi investasi dan berupaya meminimalisasi pembentukan biaya yang timbul akibat dampak penurunan kualitas kredit (biaya CKPN), hal ini sebagai respon terhadap 3 (tiga) hal penting yang menjadi dasar penentuan kebijakan perusahaan yaitu: changing in customer behavior, disrupstion and accelerated digitalization dan new competition map (fintech).

Dimensi leadership 1 Conceptual (Strategic Domain) merupakan Leadership Attribut yang mencakup kerangka dan proses berfikir seorang leader, dimana seorang leader dituntut untuk memiliki visi kedepan dan strategi yang jelas yang akan menentukan arah dan kebjakan perusahaan atau organisasi yang dipimpin, memiliki kompetnsi dalam memimpin serta mampu berfikir dan bertindak secara inovatif dan kreatif, pada domain ini Leader Level 1 sampai 3 mempunyai pendapat yang sama terkait prioritisasi dari atribut yang ada.Perbedaan prioritisasi ada pada Leader Level 2 dan Level 3, dimana pada level 2 atribut pertama Empowering Team sedang pada Level 3 lebih ke Develop People, perbedaan pada level 2 yang merupakan middle management lebih menekankan empowering baru develop karena pada level ini lebih banyak mendorong leader dibawahnya untuk lebih efektif mengelola tim dibawahnya lagi, sedang bagi leader level 3 yang mengelola garda terdepan lebih ke develop people mengingat tim dibawah mereka membutuhkan peningkatan skill dan knowledge untuk mendukung pekerjaan sehari-hari.Pada semua level leader mempunyai pemahaman yang sama dari sisi prioritisasi, namun khusus untuk leader level 3 atribut Good Communication and Deliver Message tidak hanya sebatas pada hubungan atasan-bawahan maupun sesama leader (peers) namun juga kemampuan komunikasi ke customer juga, mengingat mereka ada di garda terdepan yang langsung berhubungan dengan nasabah, komunikasi ini sangat penting karena bisnis perbankan juga sangat tergantung bagaimana karyawannya termasuk pimpinannya melakukan komunikasi dan menyampaikan (deliver) produk dan layanan yang dimikiki sehingga dapat diterima dengan baik oleh nasabah. Hasil prioritisasi dari Pandemic Attribute di atas, pada Leader Level 3 ini sangat berbeda dengan hasil validasi pada kepemimpinan Level 2 sebelumnya, dimana pada Leader Level 3 yang merupakan line manager yang langsung membawahi tim yang ada dilapangan dan berhadapan langsung dengan nasabah menunjukkan bahwa hal pertama yang harus dimiliki seorang leader adalah harus memiliki Emphaty, hal ini menjadi kunci mengingat disaat pandemi muncul kecemasan dan ketakutan dari tim yang berhadapan langsung dengan nasabah dan harus bekerja secara WFO (Work From Office), Emphaty menjadikan tim yang dipimpin merasa aman dan nyaman (safe and secure) dan kepercayaan (trust) kepada pimpinannya, sehingga walaupun bekerja penuh dengan resiko terpapar oleh virus..Temuan lain dalam penelitian bahawa kecenderungan leader dimasa pandemi adalah fokus ke people terlebih dahulu, membangun awareness atas kondisi yang ada, meyakini prosedur yang dijalankan dapat menjamin keselamatan (safe operations) baru setelah itu fokus untuk mengejar bisnis yang masih potensial untuk mendorong revenue.

\section{Daftar Pustaka}

Benuf, K. (2020). Urgensi Kebijakan Perlindungan Hukum Terhadap Konsumen Fintech Peer To Peer Lending Akibat Penyebaran Covid-19. Jurnal Rechts Vinding: Media Pembinaan Hukum Nasional. https://doi.org/10.33331/rechtsvinding.v9i2.427

Burhanuddin, B. (2020). Analisis Pengelolaan Usaha Berbasis Syariah Pada Masa Covid 19. At-Tawassuth: 
Jurnal Ekonomi Islam, (2), 377-401.

Cai, D. A., Fink, E. L., \& Walker, C. B. (2019). Robert R. Blake, With Recognition of Jane S. Mouton. Negotiation and Conflict Management Research. https://doi.org/10.1111/ncmr.12151

Dewi, K. A., Suwendra, I. W., \& Yudiaatmaja, F. (2016). Pengaruh Perputaran Kas, Perputaran Piutang, dan Perputaran Persediaan Terhadap Profitabilitas pada Perusahaan Manufaktur di Bursa Efek Indonesia Tahun 2014. E-Journal Bisma Univesitas Pendidikan Ganesha.

Drobyazko, S., Okulich-Kazarin, V., Rogovyi, A., Goltvenko, O., \& Marova, S. (2019). Factors of influence on the sustainable development in the strategy management of corporations. Academy of Strategic Management Journal.

Forster, J. J., Gill, R. C., \& Overstall, A. M. (2012). Reversible jump methods for generalised linear models and generalised linear mixed models. Statistics and Computing. https://doi.org/10.1007/s11222-010-9210-3

Ghufron, G. (2020). Teori-Teori Kepemimpinan. Fenomena. https://doi.org/10.35719/fenomena.v19i1.34

Godfrey, P. (2016). Building a Technical Leadership Model. INCOSE International Symposium. https://doi.org/10.1002/j.2334-5837.2016.00191.x

Hastuti, S. (2021). Penerapan Cost Reduction Strategies Di Masa Pandemi Covid-19 Pada Usaha Kecil Menengah (UMKM) Kota Bogor (Studi pada Anggota UMKM di Komunitas Kefir Bogor). JURNAL LENTERA BISNIS, 10(1), 78-102.

Hayet, H. (2016). Analisis Pengaruh Pertumbuhan Pembiayaan Modal Kerja, Investasi dan Konsumsi Pada Perbankan Umum Syariah Terhadap Pertumbuhan Produk Domestik Regional Bruto (PDRB) Kalimantan Barat Periode 2009-2013. Jurnal Ekonomi Bisnis Dan Kewirausahaan. https://doi.org/10.26418/jebik.v5i1.16183

Kholiq, A., \& Rahmawati, R. (2020). Dampak Implementasi Restrukturisasi Pembiayaan terhadap Likuiditas Bank Syariah pada Situasi Pandemi Covid-19. El-Barka: Journal of Islamic Economics and Business. https://doi.org/10.21154/elbarka.v3i2.2472

Kornita, S. E., \& Mayes, A. (2010). Analisis Peran Perankan Dalam Perekonomian Di Kabupaten Siak. Ekonomi. Masduki, Ida Mursidah, dan J. (2020). Jurnal Ekonomi Dan Bisnis Indonesia. Jurnal Ekonomi Bisnis Indonesia.

Meyliana, D., \& Mulazid, A. S. (2017). Pengaruh Produk Domestik Bruto (PDB), Jumlah Bagi Hasil dan Jumlah Kantor terhadap Jumlah Deposito Muḍārabah Bank Syariah di Indonesia Periode 2011-2015. Economica: Jurnal Ekonomi Islam. https://doi.org/10.21580/economica.2017.8.2.1442

Mutsanna, H., \& Sukirno, S. (2020). Faktor Determinan Opini Audit Going Concern Pada Perusahaan Manufaktur Yang Terdaftar Di Bursa Efek Indonesia Tahun 2016-2018. Nominal: Barometer Riset Akuntansi Dan Manajemen. https://doi.org/10.21831/nominal.v9i2.31600

Naway, F. A. (2017). Komunikasi dan Organisasi Pendidikan. In Gorontalo: Ideas Publishing.

Otoritas Jasa Keuangan. (2020). Statistik Perbankan Indonesia Maret 2020. Otoritas Jasa Keuangan.

PONTOH, N., PELLENG, F. A., \& MUKUAN, D. D. (2016). Analisis Profitabilitas Pata PT. Pegadaian (PERSERO) Kanwil V Manado. None. https://doi.org/10.35797/jab.4.4.2016.13806.

Putri, Y. O., Suharti, T., \& Yudhawati, D. (2019). Analisis Rasio Keuangan Untuk Mengukur Rasio Industri Perusahaan Sektor Industri Sub-Sektor Pakan Ternak. Manager: Jurnal IImu Manajemen. https://doi.org/10.32832/manager.v2i2.2570

Rosyada, M., \& Wigiawati, A. (2020). Strategi Survival UMKM Batik Tulis Pekalongan di Tengah Pandemi Covid19 (Studi Kasus pada "Batik Pesisir"Pekalongan). Jurnal Bisnis Dan Kajian Manajemen.

Saraswati, P. S. (2020). Kebijakan Hukum Terhadap Penanganan Pandemi Covid-19 di Indonesia. KERTHA WICAKSANA. https://doi.org/10.22225/kw.14.2.1923.147-152

Sari, G. (2013). Faktor-faktor yang Mempengaruhi Penyaluran Kredit Bank Umum di Indonesia (Periode 2008.1 2012.2). Jurnal Riset Ekonomi, Manajemen, Bisnis Dan Akuntansi.

Sidik, A. R., \& Sutoyo, S. (2020). Analisis Kepemimpinan Transformasional, Komitmen Dan Budaya Organisasi Terhadap Kinerja Pegawai PT. Angkasa Pura I (PERSERO) Di Masa Pandemi COVID 19. Jurnal MEBIS (Manajemen Dan Bisnis), 5(1), 69-79.

Simanjuntak, F. N., Boiliu, N. I., Tyas, E. H., Samosir, P. S. J. K. O., Limbong, M., Damayanti, M. M. A., Leniwita, H., Polii, I. V. R. S. D., Widora, S., \& Novitasari, D. T. I. . . (2020). UKI Untuk Negeri: Tantangan dan Peluang Indonesia Dalam Bidang Sosial dan Sains Pada Era Revolusi Industri 4.0. UKI Press.

Smet, A. De, \& D'Auria, G. (2020). Leadership in a crisis: Responding to the coronavirus outbreak and future challenges. In McKinsey \& Company.

Sugiyono. (2015). Metode Penelitian Pendidikan Pendekatan Kuantitatif, Kualitatif, dan R\&D. Alfabeta.

Sunarsi, D. (2018). Publisher: LPPM STIE Muhammadiyah Bandung Pengembangan Sumber Daya Manusia 
Strategik \& Karakterisrik Sistem Pendukungnya: Sebuah Tinjauan. Jurnal IImiah MEA (Manajemen, Ekonomi, \& Akuntansi).

Wang, W., Hoang, D. T., Hu, P., Xiong, Z., Niyato, D., Wang, P., Wen, Y., \& Kim, D. I. (2019). A Survey on Consensus Mechanisms and Mining Strategy Management in Blockchain Networks. IEEE Access. https://doi.org/10.1109/ACCESS.2019.2896108

Wheelen, T. L., \& Hunger, J. D. (2016). Strategic Management and Business Policy: Toward Global Sustainability. In Journal of Mathematical Sciences (United States).

Wibowo, S. W., \& Negara, M. P. I. A. (2021). Menjadi Pemimpin Yang Cerdas Di Masa Pandemi Corona Virus Disease 19 (COVID 19).

Winanto, P. S., Darmawan, P. B., \& Putri, T. E. (2020). Komparasi Kebijakan Negara: Menakar Kesiapan dan Kesigapan Menangani Covid-19. Tata Kelola Penanganan Covid-19 Di Indonesia: Kajian Awal.

Winasis, S., \& Riyanto, S. (2020). Transformasi Digital di Industri Perbankan Indonesia: Impak pada Stress Kerja Karyawan. IQTISHADIA: Jurnal Ekonomi Dan Perbankan Syariah.

Yahya, A. S. (2021). Strategi Meningkatkan Produktivitas Kinerja Aparatur Sipil Negara Selama Work From Home Di Tengah Pandemi Covid-19: Mengubah Ancaman Menjadi Peluang. Tetap Kreatif Dan Inovatif Di Tengah Pandemi Covid-19.

Yanto, A., \& Sukanta, T. (2020). Analisis Strategi Bersaing Dan Strategi Bertahan Pada Industri Mikro Dan Kecil Panganan Keripik Kemasan Di Kecamatan Coblong Kota Bandung Jawa Barat Tahun 2020 Ditengah Situasi Sulit Penyebaran Pandeml nCoV-19. JSMA (Jurnal Sains Manajemen Dan Akuntansi). https://doi.org/10.37151/jsma.v12i1.48

Yusuf, B. (2016). Manajemen Sumber Daya Manusia Di Lembaga Keuangan Syariah. In Manajemen Sumber Daya Manusia Di Lembaga Keuangan Syariah. 